\title{
10. \\ Borrowed Verse and Broken Narrative: Agency, Identity, and the (Bethesda) Sarcophagus of Bassa
}

\author{
Dennis Trout
}

Sometime in the late fourth century, a young woman named Bassa was laid to rest in the Catacomb of Praetextatus near the Appian Way, roughly two kilometres outside Rome's Aurelian walls. Bassa's marble sarcophagus - ravaged and scattered in time by vandalism and landslide but reassembled in the early twentieth century (Figure 10.1) - now stands in the handbooks as an (anomalous) example of the socalled Bethesda type. ${ }^{1}$ Thirteen other representatives of this sarcophagus group are currently known and each of these thirteen, as far as can be determined, presents the same five New Testament scenes in the same order. ${ }^{2}$ In every case, as illustrated by well-preserved examples from the Vatican cemetery and the Cathedral of Tarragona (figs. 2 and 3), ${ }^{3}$ a central tableau arranged in two registers portrays (at least in its upper half) an episode from the Gospel of John in which Jesus heals a paralytic at Jerusalem's pool of Bethesda (Jn 5.1-9). On either side of this central panel appear four other standard scenes, two on each side, and these also reference

1 On the catacomb see Spera 2004 and Spera 2006. More than thirty fragments of Bassa's sarcophagus were collected throughout Praetextatus in the late nineteenth and early twentieth centuries. Because this catacomb was significantly disturbed by ancient depredations as well as subsequent landslides and looting, it is now impossible to determine with any certainty Bassa’s original burial spot within the complex, though the recorded find spots make regions $\mathrm{D}$ and F in the NW sector of the catacomb likely: for a synopsis see Mazzei 2004, 112-113. J. Wilpert published the sarcophagus first in 1932, 294; tab. 207 no. 1. For more recent presentations see Rep.I, 229-30, taf. 85, no. 556; Nicoletti 1981,14-16, no. 4; and Koch 2000, 314, List 4, group 1.3, no. 29, Anm. 4. Einzugs-Sarkophage (Bethesda-Sarkophage). The fragments are now on display at the Catacomb of Praetextatus (non vidi); only the front panel survives: see Mazzei 2004, 111. A version of this paper was presented at the Eighth Biennial Shifting Frontiers in Late Antiquity Conference, Bloomington, Indiana, 2-5 April 2009. I would like to thank the Center for the Arts and Humanities at The University of Missouri for generous financial support and Jaś Elsner and Carl P. E. Springer for thoughtful suggestions.

2 On the order of the scenes: Simon 1938, 205; Nicoletti 1981, 1. Nicoletti 1981, 3 identifies fourteen Bethesda sarcophagi (including Bassa's) but fragments represent the majority; see also Koch 2000, 314-15 for the same number.

3 Vatican: Rep. I, 59-60, taf. 20, no. 63; Nicoletti 1981, 7-9, no. 1. Tarragona: Sotomayor 1975, 213-219, no. 38; Nicoletti 1981, 9-12, no. 2. 


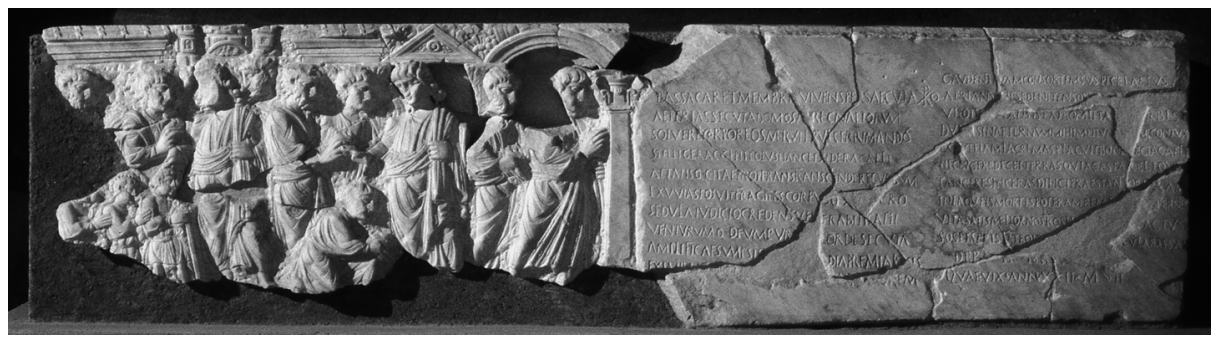

Figure 10.1: Rome, Museo cristiano delle catacombe di Pretestato. The sarcophagus of Bassa. Photograph: Foto Archivio, P.C.A.S.

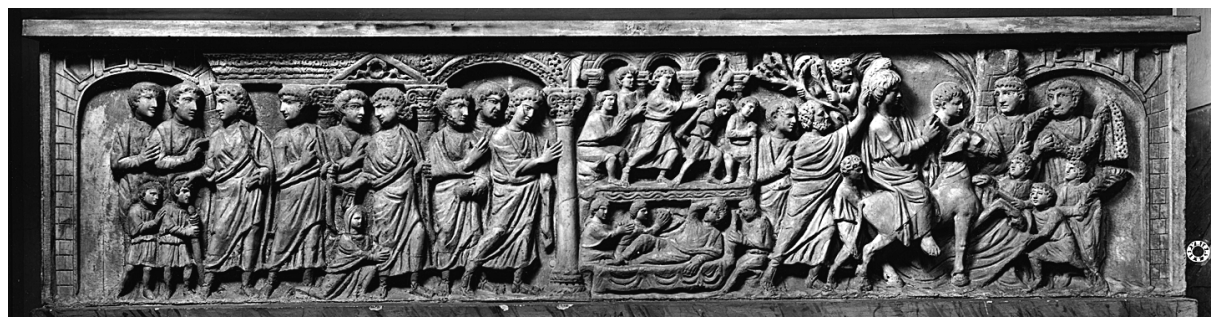

Figure 10.2: Città del Vaticano, Museo Pio Cristiano. Bethesda sarcophagus (Art Resource)

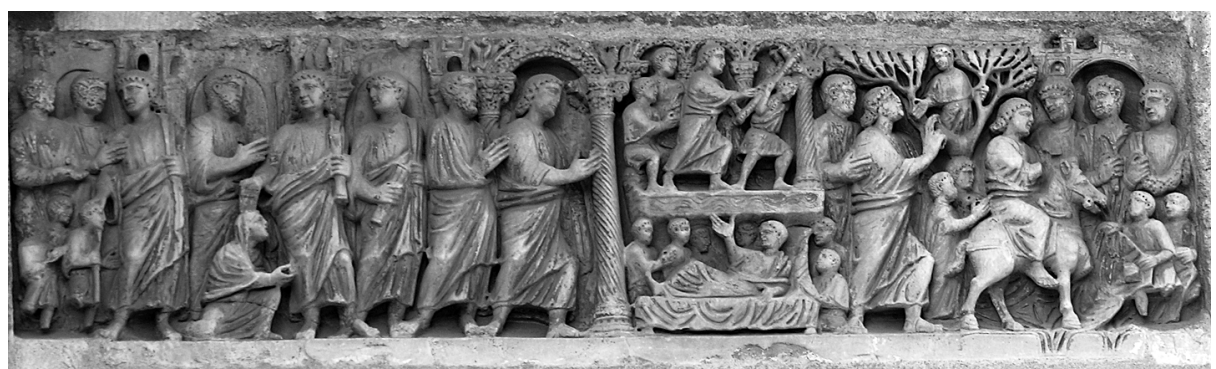

Figure 10.3: Tarragona, Cathedral. Bethesda sarcophagus (courtesy of J.Elsner)

gospel events (two scenes of wonder working, Zacchaeus in the sycamore tree, and Jesus' final entry into Jerusalem).

In the unique case of Bassa's sarcophagus a verse epitaph (ICUR 5.14076), sampling expressions found elsewhere and disrupting the type's figural flow, occupies the front panel's entire right half, replacing not only the Bethesda type's final two scenes (Zacchaeus and Jesus' entry) but also its central eponymous panel. Though easily dismissed as awkward and inept, the idiosyncratic design of Bassa's sarcophagus may rather testify to the ingenuity with which several otherwise unknown Romans - Bassa, her husband, Gaudentius, and the artisans of one city workshop - manipulated ideas and art forms in order to fashion and express social 
identity in late ancient Rome. ${ }^{4}$ From this perspective, Bassa's sculpted and inscribed coffin is both a striking 'index' of social agency in this age of cultural transformation and an eloquent witness to the less sensational ideological negotiations undergirding the genesis and evolution of late antique Roma Christiana. ${ }^{5}$ The following discussion begins with the text of Bassa's epitaph, moves on to consider her sarcophagus' Bethesda imagery, and concludes with a synthetic reading of her compelling memorial.

\section{The Epitaph}

Of the more than thirty fragments of Bassa's sarcophagus recovered from the debris of Praetextatus' subterranean galleries, eleven preserve her epitaph - nearly entire (figs. 4 and 5). ${ }^{6}$ The text, which is original to the design and not retrofit onto a previously sculpted and erased surface, ${ }^{7}$ is arranged in two columns each of ten hexameter lines. ${ }^{8}$ A chi-rho, which also serves as the last word of the first line, is prominent between the two columns. Above the first line on the left are the traces of the same line in red paint. Below the last line on the right are the date of Bassa's deposition - one day before the calends of a missing month - and her age - twenty-

4 Our Bassa and Gaudentius cannot otherwise be identified nor can their social rank be determined with any certainty. That they were of at least moderate wealth is evident. Dresken-Weiland 2004, 150 suggested that the presence of a metrical epitaph points to an 'ambiente senatorio' for the couple but versification may just as well indicate social or literary aspirations among those of lower rank. See for example the verse epitaph of Celerinus, just a presbyter, cited below. Similarly for acrosticha (as is Bassa’s epitaph); Sanders 1991, 200 sees the acrostic epitaph as a form favoured by the 'classes moyennes' including ecclesiastics. Furthermore, Dresken-Weiland's sample of 310 inscribed early Christian sarcophagi from Rome yields only sixty-nine of sure 'ceti elevati' (forty-six of which are senatorial) and otherwise includes soldiers, a casarius (cottager), and a grammaticus. Nomenclature is also of little help. Gaudentii appear across the Italian social spectrum as represented, for example, by clerical office holders; see e.g., Pietri and Pietri 1999, 887-892, 'Gaudentius 2-10,' from fossor to bishop. Bassae, the indices of ICUR reveal, are (surprisingly) rare: but see ILCV 2799 (a virgo); ILCV 3878 (apparently an agnomen), neither of high social rank; and CLE 1058, the verse epitaph of an earlier Bassa, whom 'Pluto rapuit . . . ad infera templa.'

5 Gell 1998, especially 12-21, supplying a rationale for viewing Bassa's sarcophagus as an artefactual index of social agency. Mazzei 2004, 113, too, recognised as much, seeing in the incorporation of the epitaph 'un ingerenza particolarmente volitiva da parte del committente.'

6 Wilpert 1932 knew nine fragments of Bassa's epitaph. A tenth fragment, the end of lines 3-6 of column B, was added by E. Josi in 1935, who then re-published the text at Josi 1935, 12-13. In 1947 A. Ferrua identified an eleventh fragment of the inscription, the end of the final line of column A, before publishing the epitaph in 1971 as ICUR 5.14076. See Mazzei 2004, 115 for confirmation after restoration.

7 Nicoletti 1981, 16; Mazzei 2004, 113.

8 Bassa's epitaph is thus one of a group of 'circa 350' Christian metrical funerary inscriptions from Rome; see Carletti 1998, 61. 


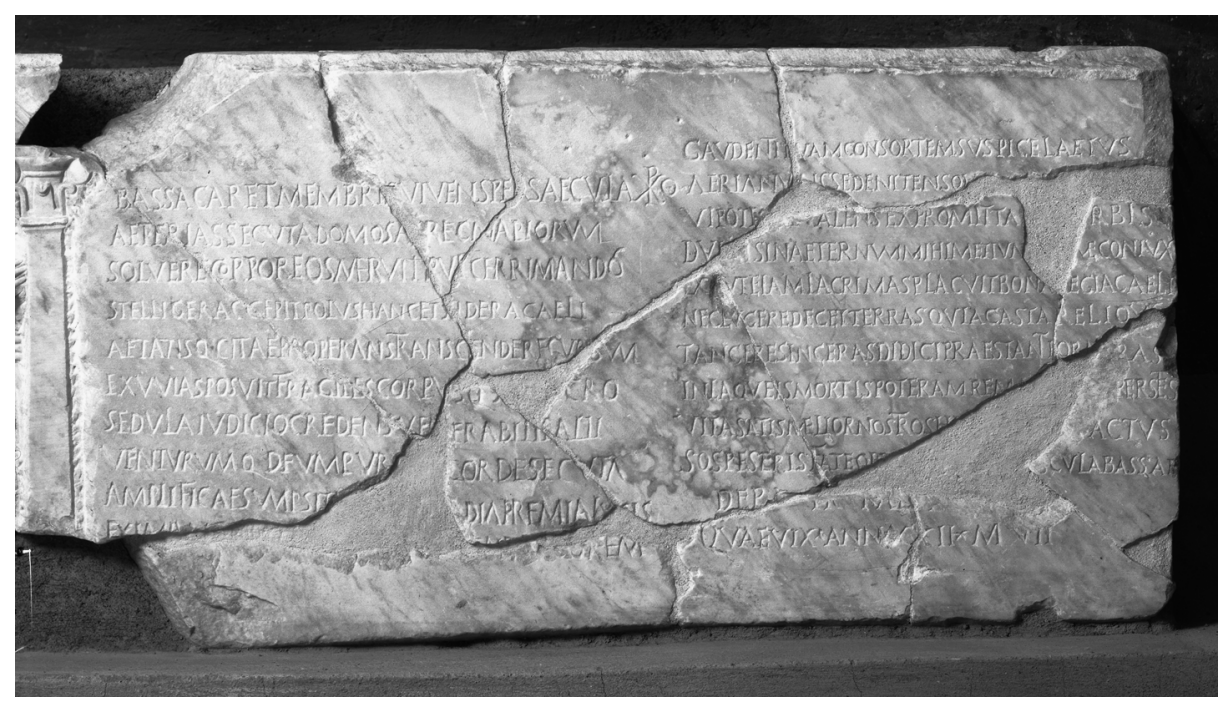

Figure 10.4: The Sarcophagus of Bassa: Epitaph. Photograph: Foto Archivio, P.C.A.S.

two years and seven months. The poem is an acrostic, a bit of panache that appears to have been popular among fourth-century Christians at Rome. ${ }^{9}$ The first letters of each line spell out Bassae suae (on the left) and Gaudentius (on the right), that is, 'to his Bassa, Gaudentius.'

The right-hand column (A) envisions Bassa's disembodied ascent from her tomb to a lucent home in a starry heaven:

\section{[B] assa caret m[emb]ris}

Bassa caret membris vivens per saecula Xpo

Aeterias secuta domos ac regna piorum

Solvere corporeos meruit pulcerrima nodos;

Stelliger accepit polus hanc et sidera caeli

Aetatisq(ue) citae properans transcendere cursum

Exuvias posuit fragiles corpusq(ue) s[epu]lcro;

Sedula iudicio credens venerabilis $A l[t] i$

Venturumq(ue) deum puro [cum] corde secuta

Amplificae sumpsit [sibi gau]dia premia lucis

Eximium [..... umq]ue [de]corem. ${ }^{10}$

9 Of the eighty-six acrostic carmina Latina epigraphica (including ICUR 5.14076) counted by Sanders 1991, 193-197, forty are considered 'pagan' and forty-six Christian while only one of the former, but twelve of the latter, can be dated to the fourth century.

10 ICUR 5.14076. Line 2: for aetherialas/is/um as the opening word in ten Vergilian lines see Warwick 1975, 34. Line 4: cf. Statius, Thebaid 12.565, 'stelligeri iubar omne poli; 


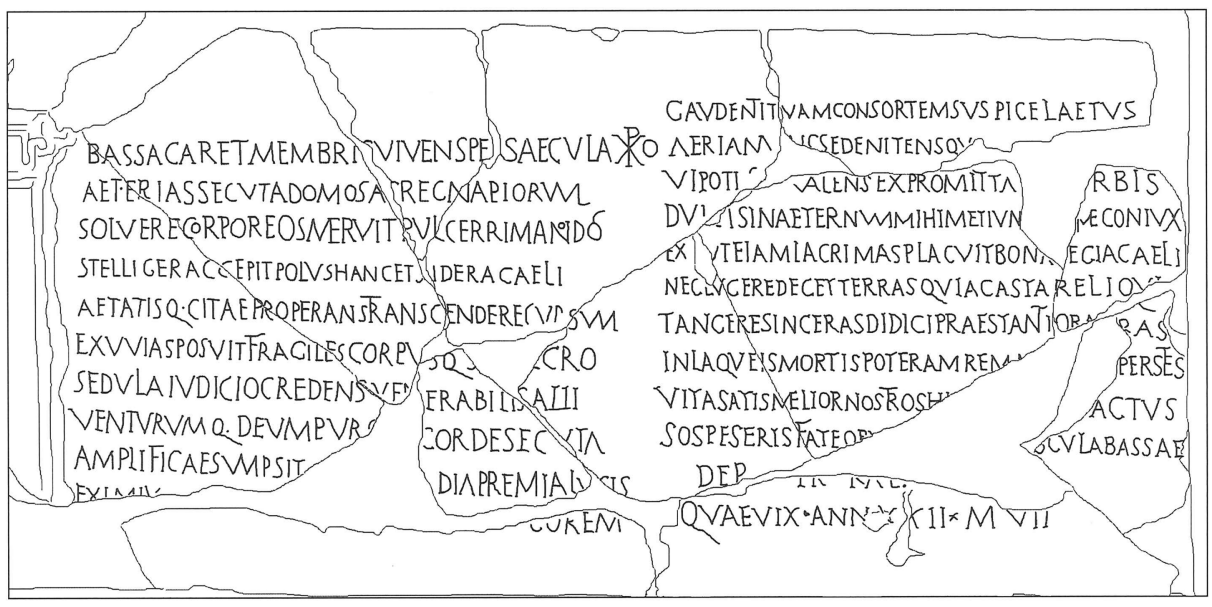

Figure 10.5: The Sarcophagus of Bassa: Epitaph, apograph by B. Mazzei.

Photograph: Foto Archivio, P.C.A.S.

Bassa is free of her limbs, living through the ages in Christ.

Pursuing an ethereal home and the kingdoms of the pious, most beautiful, she deserved to loose the knots of the flesh. Star-bearing heaven and the stars of the sky have received her and hastening to move through the course of swift passing life, she has placed her fragile husk and body in the tomb. Worthy of respect, steadfastly trusting in the judgment of the high God, and attending with pure heart the God who will come, she has taken to herself the pleasures (and) rewards of the boundless light distinguished ...... and beautiful.

The left hand column (B) consoles Gaudentius, in part through an address from Bassa herself, who speaks to her husband from heaven's court with the promise of their future reunion:

\section{Gaudenti tuam consortem suspice laetus}

Aeria nunc sede nitens qu[ae. . .

Vi potiore valens expromit tallia ve]rbis:

Dul[c] is in aeternum mibimet iun[tissi]me coniux

sidera caeli' at Ver. Aen. 1.259 (Aeneas' place of reward as promised to Venus by Jupiter), Geo. 2.1, and Geo. 4.58. Line 5: cf. Ver. Aen. 6.313, 'transmittere cursum.' Line 7. Altus for God is unusual, as Ferrua noted; the superlative, Altissimus, is known: cf. Ps 91.2; Dan 4.21. Line 8: for the frequent appearance of secutalaeli/um/us in this position in the Vergilian hexameter see Warwick 1975, 769-770. For other poetic echoes see below. 
Ex[c]ute iam lacrimas, placuit bona [r]egia caeli;

Nec lugere decet terras quia casta reliqu[i];

Tangere sinceras didici praestantior a Uu]ras;

In laqueis mortis poteram rema[nere su]perstes;

Vita satis melior nostros hi[c . . . . . . ]actus;

Sospes eris fateor v[ . . . . o]scula Bassae.

dep(osita) pr(idie) kal(endas). . . .

quae vix(it) ann(os) XXII m(enses) VII

Gaudentius, happily look up at your wife, who shining brightly now in her lofty abode. . . prevailing with renewed strength, utters such things in words:

'Sweet husband, most closely bound to me forever, drive off your tears, the noble court of heaven is pleasant, and it is not fitting to weep because I, a virtuous woman, have abandoned earth; More pre-eminent I have learned how to take hold of the pure upper air;

in the snares of death I was able to remain alive;

A much better life... .

You will be saved, I confess . . . the kisses of Bassa.'

Bassa's epitaph generally adheres to the standards of quantity and prosody inherited from the poetry of the past and common to the carmina epigraphica of the later fourth century. ${ }^{11}$ Nor are the verses without their charm. The acrostic aligns her poem not only with the literary aspirations of a number of other fourth-century epitaphs but also, in effect, with the kind of cultural pretensions already displayed in the prodigiously laborious carmina figurata of Optatianus Porfyrius or still to come, for example, in the sixth-century verses of Venantius Fortunatus. ${ }^{12}$ This cleverness and effort variously leave their mark in word play and arrangement. The poem begins and ends with Bassa's name while Gaudentius stands at mid-point as the first word of the second column (as hers is of the first) - and thus the first letter in each column reads as the first letter of each name both horizontally and vertically. Furthermore, the gaudia of A9 anticipate the naming of Gaudentius just two lines later, much as the heavenly 'pleasures' embraced by Bassa are prelude to her reception of her husband in the

11 There are no elisions. In A2 the first syllable of secuta must be lengthened, although at A8 the same syllable is properly scanned as short. At B1 we should expect laete for laetus, that is, a vocative in agreement with Gaudenti not a nominative, but such a deviation is otherwise known in contemporary inscriptions. Finally, and in the same line, the first syllable of tuam also has to be lengthened.

12 See above note 9 with Levitan 1985 and Graver 1993. 
regia caeli. If the poem's final line did indeed read 'Sospes eris fateor ulenies et ad o]scula Bassae (You will be saved, I confess, and will come to the kisses of Bassa)' - as Antonio Ferrua suggested - then word play may also have ended the epitaph: Bassae, juxtaposed with oscula as the final two words of the poem, may have evoked for some readers the poetic but rare basia (kisses), punning upon her name but also reinforcing the conjugally erotic tenor of the piece. ${ }^{13}$ There are, of course, echoes of Vergil, direct or otherwise, while alliteration and end rhyme decorate several lines, further testifying to the care lavished on composition. ${ }^{14}$

Especially striking, however, is the vigour with which Bassa lays claim to a specifically astral afterlife. Celestial imagery cascades from the poem - aeterias domos, premia lucis, aeria sede, and sinceras auras - but is brilliantly concentrated in the stelliger polus and sidera caeli that surround Bassa (hanc) in the fourth line of the first column - or better, amid which Bassa rests just before the line's caesura. Yet if Bassa's enthusiasm for the stars appears unusually strong, it is hardly unique. Bassa's eminently noble contemporary, Petronius Probus (whose sepulchral poem manifestly puns upon his name) was interred at St. Peter's but nevertheless, his lengthy verse epitaph proclaimed, lived on to possess the stars (vivit et astra tenet). ${ }^{15}$ Rather less exalted in life but no less grand in his designs was the otherwise unknown presbyter, Celerinus, who abandoned his body at $S$. Agnese in order to rejoice among those same stars (qui gaudet in astris). ${ }^{16}$ In this company the eighty-six year old inlustris femina, Decentia, vouches for the notion's continuing appeal a century on: sidera me retinent, declared her epitaph. The stars possess me! ad vitam redii. ${ }^{17}$

The sources of this poignant astral longing are distant, though earlier at Rome the sublime heights reached out for by such late ancient Christians as Bassa and Probus were reserved for civic benefactors of heroic stature and, eventually, emperors. In the second century BCE Quintus Ennius, in an

13 Ferrua at ICUR 5.14076, noting that Josi's [per cuncta sae]culae Bassae violated both the marble and the meter. The potential word play, pointed out to me Carl P. E. Springer, further favours the supplement.

14 On Vergil see above note 10 and below. A3 is nicely alliterative; A8 offers a series of -um endings.

15 CIL 6.1 1876, 389 ad nos. 1751-1756 = CLE 1897, $1347=$ ILCV 1924-1931, $63=$ ICUR 2 1935, 4219. Probus died about 390. See PLRE 1 1971, 736-740, 'Probus 5,' and Trout 2001, 157-176.

16 CLE $668=$ ILCV $1129=$ ICUR 8.20798: Praesbyter hic situs est Celerinus nomine dic[tus], / corporeos rumpens nexus qui gaudet in astris. From S. Agnese on the Via Nomentana with a consular date of 381. See Pietri and Pietri 1999, 426, 'Celerinus 1;' Rüpke and Glock 2008, 606, 'Celerinus 3'. For his sister, Aemiliana, interred in the same catacomb, see ILCV 1129n = ICUR 8.20878.

17 CLE 1363 = ILCV 217a: sidera me retinent ... ad vitam redii. Quae vixit annos p(lus) m(inus) LXXVI. Early sixth century? See PLRE 2 1980, 348, 'Decentia'. 
epigram penned as a pseudo-epitaph for Scipio Africanus, had already opened 'heaven's great gate' and the 'regions of the heavenly gods' to the victor over Hannibal: 'If it is permissible for anyone to ascend to the regions of the heavendwelling gods,' Scipio's 'epitaph' boasted, 'Heaven's great gate lies open to me alone. ${ }^{18}$ The appealing notion would, of course, find its worthy echo in Cicero's reflections on service to the res publica. ${ }^{19}$ But the conceit of celestial reward granted for special merit and virtus exercised on behalf of the state, finds its early apogee in the language used by the Augustan poets to describe the apotheosis of Caesar or forecast the heavenly prize awaiting Augustus himself. ${ }^{20}$ It is especially telling, of course, that the concept found manifold expression in the one text, Vergil's Aeneid, whose influence over fourth-century ways of thinking (and writing poetry) is virtually incalculable. ${ }^{21}$ It was, for example, through displays of manliness, Apollo informed the epic's young Iulus (9.641), that men might reach the stars: 'A blessing on your new virtus, boy, sic itur ad astra.' So, too, Jupiter would remind Juno that Aeneas (as Indiges) was owed to the heavens and would be raised to the stars (ad sidera tolli) by the Fates (12.794-95). Even the manly Dido knew as much: fama, she proclaimed, was her sole pathway ad sidera. ${ }^{22}$

It was more likely the burgeoning cult of the martyrs, however, rather than the late antique cultivation of Vergil, that most immediately inspired and shaped the imagery of many late fourth- and early fifth-century private epitaphs intent upon charting a course to the astral zone. Here there is only time to draw attention to the singular influence of the elogia of Damasus, bishop of Rome from 366 to 384, both upon the character of Bassa's epitaph itself and also more generally upon the late-fourth-century resurgence of the epigraphic habit and revitalisation of the carmen epigraphicum at Rome. ${ }^{23}$ Throughout the Roman suburbs, in proximity to the tombs of the city's early Christian heroes, Damasus installed dozens of elegantly inscribed marble tablets celebrating (however vaguely) in Vergilian inspired verse the res gestae of martyrs whose sepulchers' (like Bassa's) retained only corpora and membra and whose animae (like hers)

18 Courtney 1993, 40-42, 'Ennius 44': si fas endo plagas caelestum ascendere cuiquam, I mi soli caeli maxima porta patet.

19 Cicero, De re publica 6.15-29 (the Somnium Scipionis): ea vita via est in caelum (6.16).

20 On the numismatic and poetic evidence for Octavian/Augustus' appropriation of the sidus Iulium see Gurval 1997.

21 See, for example, MacCormack 1998; McGill 2005; Green 2006 and the essays in Rees 2004 and Scourfield 2007.

22 Aen. 4.322-323: ... qua sola sidera adibam, I fama prior.

23 On the central role of Damasus' verse elogia and epitaphs in this regard see Carletti 2001, $335,347,380$. 
had shot heavenward. ${ }^{24}$ At the Catacomb of San Callisto, on the Via Appia, not far from Bassa's resting place, revered tombs - Damasus had proclaimed preserved the 'bodies' of a 'throng of the pious' though the 'palace of heaven' had snatched up their spirits. ${ }^{25}$ In the same neighbourhood, at the Basilica Apostolorum (and in lines and phrases that reappeared on Bassa's sarcophagus) Peter and Paul followed Christ per astra to reach the aetherios sinus regnaque piorum, where Damasus hailed them as Rome's nova sidera - as once Vergil had cast Octavian (not yet Augustus) as Rome's 'new star'. ${ }^{26}$

Indeed, no text better illustrates the drift of concepts and language from the 'official' commemorative elogia of the martyrs to the graves of ordinary Romans than Bassa's epitaph. The debts are manifest in expression alone. The phrase regna piorum, for example, which ends the second line of the first column of Bassa’s epitaph, had earlier appeared in Damasus' elogium for Hippolytus on the Via Tiburtina (35.4) while the variant regnaque piorum concludes a line in four other Damasan elogia $(25.4,43.5,39.8)$, one of which is the elogium for Peter and Paul installed at the Basilica Apostolorum (20.5). The collocations aetheriam domum, aetherias domus, and deum venturum, which are apparently echoed in lines two and eight of the first column of Bassa's epitaph, each appear once in a Damasan poem (43.5, 25.2, and 39.2 respectively) while the Virgilian tag regia caeli, which ends line five of the second column, appears in the same position in four Damasan martyrial elogia, as well as in his epitaph for his sister Irene $\left(16.3,25.2,39.4,47.3 ; 11.11\right.$ [Irene]). ${ }^{27} \mathrm{~A}$ number of these elogia, it is worth noting, as well as Irene's epitaph, were installed in complexes in the general vicinity of the Catacomb of Praetextatus.

But one Damasan elogium was, in fact, on display quite close to hand. In the area of the so-called spelunca magna of the same catacomb complex, that of Praetextatus, that would receive Bassa's sarcophagus, Damasus had installed a text honouring the martyrs Felicissimus and Agapitus. Three pieces of the

24 E.g. Curran 2000, 148-155; Trout 2005, 298-315, both with bibliography. On Damasus' poetics and the role of Vergil therein see Fontaine 1981, 111-125, but especially 119-122; Fontaine 1986, 115-145.

25 Ferrua 1942, 16.1-3: Hic congesta iacet quaeris si turba piorum. / corpora sanctorum retinent veneranda sepulcra. I sublimes animas rapuit sibi regia caeli. All further references are to Ferrua's edition. On line 16.3 note the echoes of Ver. Aen. 5.254-255: quem (Ganymede) praepes ab Ida / sublimem pedibus rapuit Iovis armiger uncis; 6.719-720: putandum est / sublimis animas iterumque ad terra reverti / corpora?; and 7.210: regia caeli.

26 Damasus, 20. 4-7: sanguinis ob meritum Xpumq(ue) per astra secuti / aetherios petiere sinus regnaque piorum: / Roma suos potius meruit defendere cives. / Haec Damasus vestras referat nova sidera laudes. Ver. Geo. 1.32: anne novum tardis sidus te mensibus addas. On the imagery of early imperial apotheosis see Gurval 1997, and Gradel 2002, 291-320, with stars on coins commemorating divus Augustus (fig. 12.1 A) and diva Faustina Maior (fig. 12.3 J). On a Damasan jab at the Dioscuri see Trout 2005, 304-305.

27 Ver. Aen. 7.210 (on the apotheosis of Dardanus): aurea nunc solio stellantis regia caeli. 
original marble tablet were discovered in 1927 in the pavement of S. Nicola dei Cesarini, which in 1132 had been built into Temple A of the Largo Argentina complex. The full text, however, had long been known from a late antique copy. ${ }^{28}$

Aspice, et hic tumulus retinet caelestia membra

Sanctorum subito rapuit quos regia caeli.

Hi crucis invictae comites pariterq(ue) ministri

Rectoris sancti meritumq(ue) fidemq(ue) secuti

Aetherias petiere domos regnaq(ue) piorum.

Unica in his gaudet Romanae gloria plebis

Quod duce tunc Xysto Xpi meruere triumphos.

Felicissimo et Agapeto martyrib(us) Damasus episc(opus) fecit.

Behold! This tomb, too, preserves the celestial limbs

of saints whom suddenly the palace of heaven snatched up.

These, at once comrades and attendants of the unconquered cross, imitating both the merit and the faith of (their) holy bishop,

won an ethereal home and the realms of the pious.

The singular glory of the Roman people rejoices in them

because with Sixtus at that time as their leader they gained Christ's triumphs.

For Felicissimus and Agapitus, the holy martyrs, Damasus the bishop made (this).

Regia caeli and secuti appear in this elogium with the same semantic value and in the same metrical position as they do in Bassa's epitaph but, most tellingly, line five of Damasus' epigram for Felicissimus and Agapitus must be the inspiration for the second line of the first column of Bassa's epitaph: Damasus' aetherias petiere domos regnaq(ue) piorum has become in the hands of the author of Bassa's epitaph aeterias secuta domos ac regna piorum. ${ }^{29} \mathrm{~A}$ bit of clumsiness in the adaptation, requiring the lengthening of the normally short first syllable of

28 Damasus, 25. For the details see Ferrua 1942, 152-156. There were at least two other Damasan elogia in the same general area: 24 (Januarius) and 27 (Quirinus?). Fragments of another (26) point to a third. For the debate on the exact location of the memoria of Felicissimus and Agapitus see Tolotti 1977, 82-87; Spera 2004, 192-205, and Spera 2006, 257.

29 Already noted by Wilpert 1932, 294 and Ferrua 1942, 154. For a similar construction note Damasus 39.5: aeternam petiere domum regnaque piorum, for the martyrs Felix and Philip at the catacomb of Priscilla. 
secuta, only highlights the dependency. ${ }^{30}$ In short, if all we now possessed were a pilgrim's copy of Bassa's epitaph, we would be happy to draw from such evidence further conclusions about the influence of Damasus' monumental elogia on the literary and imaginative sensibilities of Rome's everyday Christians - and remark how easily commemorative strategies and poetic language leaked from martyr cult to private tombs in late fourth-century Rome, opening the starry heavens to some whose claims upon the ethereal realm arose neither from the kind of bloody self-sacrifice made by the martyrs nor the lofty social rank of a consularis such as Petronius Probus but from their professed enactment of less spectacular religious and conjugal ideals. ${ }^{31}$

\section{The Visual Imagery}

Bassa's epitaph, however, is also a predominant component of a visual field (Figure 10.1). And although, the relatively rough and uneven finish accorded to the sculpted images may be evidence of priority given to the inscribed text, ${ }^{32}$ it is especially the monument's unusual melding of poetic language and figural images that establishes it as striking testimony to the complex mechanisms of agency and identity in late ancient Rome. As previously noted, all other representatives of the Bethesda group (see Figures 10. 2 and 10.3) apparently reproduce the same sequence of scenes. ${ }^{33}$ Not only the particular images,

30 See above note 11 . In line eight of the same column, however, secuta, in the Damasan position at the line's end, scans properly.

31 Carletti 1998, 51-53, on such language of merit as castus/a and the preference for coniunx.

32 On the apparently incomplete aspects of the sculpted relief, unpolished and without drillings, see Nicoletti 1981, 16 and Mazzei 2004, 113-114.

33 Art historians concerned with the classification, chronology, workshops, and style of Christian sarcophagi have variously assessed the Bethesda type. Lawrence 1927, 23-24 initiated debate by construing the Bethesda type as a subset of the city-gate type (itself, in her view, a subset of the columnar type) and dating the city-gate group to the later fourth century, a dating now generally accepted on stylistic grounds. But Lawrence also argued that the city-gate type was a continuation of 'Asiatic' traditions of iconography, style, and ornament, though allowing that the Bethesda subset represented, in her view, a 'mixed' form, incorporating elements of the western 'frieze' tradition. In a subsequent study, Lawrence 1932, 103-185 further identified the workshops of southern Gaul, perhaps staffed by eastern craftsmen, as the medium through which such 'Asiatic' influences (along with unfinished columnar sarcophagi) reached Rome. See esp., 121-122, for her assignment of both Red Sea type and Bethesda type sarcophagi, including the Tarragona (Nicoletti 1981, no. 2; Koch, 2000, 315, no. 38) and Vatican (Rep. I, no. 63) examples illustrated here (figs. 2 and 3) to a Gallic atelier (she was not yet aware of Bassa's sarcophagus). Scholarly opinion, however, now favours a Roman origin for the Bethesda type and identifies Roman workshops as the certain source of the two examples from 
therefore, but also the regularity of their order must have determined how some ancient viewers read the Bethesda type - and thus responded to its manipulation by the patrons who commissioned and the artisans who carved Bassa's sarcophagus. A brief discussion of the general type's scenes is, therefore, in order.

The group's central, emblematic scene is universally understood to reference (at least in its upper register) a healing miracle recounted only in the Gospel of John $(5.1-9)$ :

Some time later, Jesus went up to Jerusalem for one of the Jewish festivals. Now at the Sheep Gate in Jerusalem there is a pool whose Hebrew name is Bethesda. It has five colonnades and in them lay a great number of sick people, blind, lame, and paralysed. Among them was a man who had been crippled for thirty-eight years. Jesus saw him lying there, and knowing that he had been ill a long time he asked him, 'Do you want to get well?' 'Sir,' he replied, 'I have no one to put me in the pool when the water is disturbed; while I am getting there, someone else steps into the pool before me.' Jesus answered, 'Stand up, take your bed and walk.' The man recovered instantly; he took up his bed and began to walk. ${ }^{34}$

Most often the Bethesda type's depiction of this episode is seen to unfold in a serial narrative that moves from the lower to the upper register of the central tableau and embraces the figure of Christ just to the left of this tableau. ${ }^{35}$ In the lower half, the cripple lies on his pallet, waiting to be carried into the pool's healing waters, and gestures towards the approaching figure of Christ; in the upper half, he has apparently fulfilled Christ's command, 'Stand up, take your bed and walk'. ${ }^{36}$ Fidelity to the details of John's account - the colonnade above and wavy water lines on the horizontal divider - leave no doubt that the Bethesda episode is represented in the upper register. ${ }^{37}$ In 1985, however, Françoise Monfrin, echoing an observation of Manuel Sotomayor, noted the striking differences in the design of the bed and especially the clothing of the sick man portrayed in the two registers. Sotomayor had explained the contrast

Rome (Bassa's and the Vatican sarcophagus) and perhaps for the Spanish and North African Bethesda examples, while recognising that the fragmentary Gallic examples were most likely locally carved; see the summary at Nicoletti 1981, 4-6, 79-90, and the scheme of Koch 2000, 298-302, who classifies the Bethesda type as 'die EinzugsSarkophage (Bethesda-Sarkophage)' and makes it a subset of the single frieze type ('Einzonige Fries-Sarkophage') of the 'valentiniansch-theodosianischen Zeit'.

34 Translation: The Oxford Study Bible (New York, 1992). The episode is unusually detailed by New Testament standards and may target the healing cult of Asclepius; see Knipp 1998, $151-153$.

35 E.g. Wilpert 1932, 293; Nicoletti 1981, 64-66; Knipp 1998, 149-52.

36 Jn 5.8: surge tolle grabattum tuum et ambula. All biblical citations (despite the possible anachronism) are from the Biblia Sacra Iuxta Vulgatam Versionem (Stuttgart, 1994). Knipp 1998, 143-149 offers detailed description.

37 See Minasi 2000, 242 on the rarity of representations that clearly distinguish the healing at Bethesda from the healing of the paralytic at Capernaum recorded in the synoptic gospels (Mt 9.1-8; Mk 2.3-12; Lk 5.5.18-16). 
between the tunic and pallium of the main figure in the lower register and the simpler sleeveless (exomis) tunic of the paralytic in the upper register as a double reference to the same Bethesda episode, which he thought was portrayed descriptively above but typologically below, where the reclining figure's more ornate dress was intended to suggest the regeneration of baptism. ${ }^{38}$ Monfrin, however, argued that the contrast between the upper and lower 'paralytic' made problematic any identification of them as representations of the same individual at two stages of the Bethesda miracle narrative. Moreover, Monfrin suggested that the lower scene was iconographically reminiscent of a prothesis or conclamatio, the lamentation over the dead or dying, and represented a different healing episode from that shown in the upper register. He argued, therefore, on iconographic, scriptural, exegetical, and liturgical grounds, that the most likely scriptural source for the lower scene was Christ's healing (at Capernaum) of the servant of the centurion, which appears in Matthew (8.5-13) and Luke (7.110) and was at times conflated with John's account (4.43-54) of Christ's healing of the son of the royal official, an episode set in Galilee immediately prior to John's account of the healing at Bethesda. ${ }^{39}$ Despite persistent argument for the unity of the two scenes, Monfrin's critique has raised significant and unresolved questions about the identification of the lower register of the central tableau. ${ }^{40}$ What that critique does not deny, however, and what must have been evident to all ancient viewers, is that both registers, upper and lower, unambiguously advertised Christ's salvific power.

Christ's power to heal miraculously is equally on display in the two scenes to the left of the central panel. On the far left Christ restores the sight of two (or three) blind men in a scene often equated with a Gospel episode set at Jericho, though other scriptural candidates are possible and certainty is unlikely, even perhaps unnecessary. ${ }^{41}$ Between this scene and the central scene appears a woman kneeling before Christ, who holds his right hand over or atop her head. On the basis of the posture and gestures of the woman and the figure of Christ, it has seemed preferable to see here a representation of the haemorrhaging woman cured by touching Christ's clothing. ${ }^{42}$ To be sure other candidates have been proposed: the suppliant Canaanite or Phoenician woman of Matthew

38 Sotomayor $1975,217-218$.

39 Monfrin 1985, 979-1020.

40 Nicoletti 1981, 65-66, had responded to Sotomayor; as would Knipp 1998, 155-160 but without notice of Monfrin.

41 Mt 20.29-34, the only New Testament text that offers a double healing. See Simon 1938, 206 and Nicoletti 1981, 40-46, with discussion of sources and comparanda. For the possibilities see also Ranucii 2000, 200. On entertaining ambiguity see Monfrin 1985, 999-1000. Note that the Tarragona sarcophagus and Bassa's portray three blind figures; see Nicoletti 1981, 9-10, 14-15.

42 Matt 9.20-22; Mk. 5.25-34; Lk 8.43-48 with Nicoletti 1981, 47-52. 
15.22 and Mark 7.25, ${ }^{43}$ and Mary, the sister of Lazarus, whose appeal before Christ is known from John $11.32 .{ }^{44}$ In any case, many ancient viewers, even if similarly uncertain, should nonetheless have understood this supplication scene, buttressed by incontestable scenes of healing to its left and right, as another display of Christ's curative powers. To the right of the central tableau unfold two further easily identified New Testament scenes. The first portrays Luke's account (19.2-8) of the calling of the tax-collector Zacchaeus, perched in the sycamore tree from which he hoped to catch sight of Jesus as he passed through Jericho en route to Jerusalem. ${ }^{45}$ The final scene then illustrated Christ's (triumphal) entry into Jerusalem itself, seated upon a donkey and greeted with shouts of Hosanna and the waving of palm branches. ${ }^{46}$

Typically the identification of scenes, especially the first two on the left, has responded to assumptions or arguments about the overall meaning and message of the Bethesda type. And this, too, understandably has provoked various reflections. M. Simon in 1938, for example, and more recently Galit NogaBanai, intrigued by the architectural detail of the central scenario and the unusually regular sequencing of the other images, have keyed the type's message to a pilgrim's or reader's experience and understanding of Holy Land topography. ${ }^{47}$ Other interpretations, less closely bound to material realia, have drawn attention to contemporary catechetical instruction and exegetical strategies that loaded the episode of the waters of Bethesda with baptismal overtones. ${ }^{48}$ But in a funerary context, as Monfrin also stressed ${ }^{49}$ many viewers must naturally have read the progression from easily allegorised scenes of healing to the resurrection alluded to by Christ's Jerusalem advent as a narrative of divine power and salvation that had profound implications for their own eternal welfare. ${ }^{50}$ That is, the extraordinary momentum of narrative and design that draws the viewer forward through the miracle series to the threshold of

43 Wilpert 1932, 293; Monfrin 1985, 999-1000.

44 Simon 1938, 213-215.

45 Nicoletti 1981, 69-71, distinguished here (by the repetition of the figure of Christ) from the entry scene itself, in which Zacchaeus had been included when previously represented.

46 Nicoletti 1981, 72-73; Mathews 1999, 27-28 on the popularity of the scene on western sarcophagi.

47 Simon 1938, 200-223; Noga-Binai 2007, 107-123.

48 See, for example, the discussions at Monfrin 1985, 984 and 994-995, who sees the baptismal typology as overly subtle; Knipp 1998, 155-158; and Noga-Binai 2007, $112-113$.

49 Monfrin 1985, 997-999.

50 On the importance of 'social context' to the construction of meaning see Elsner 1995, $249-287$. 


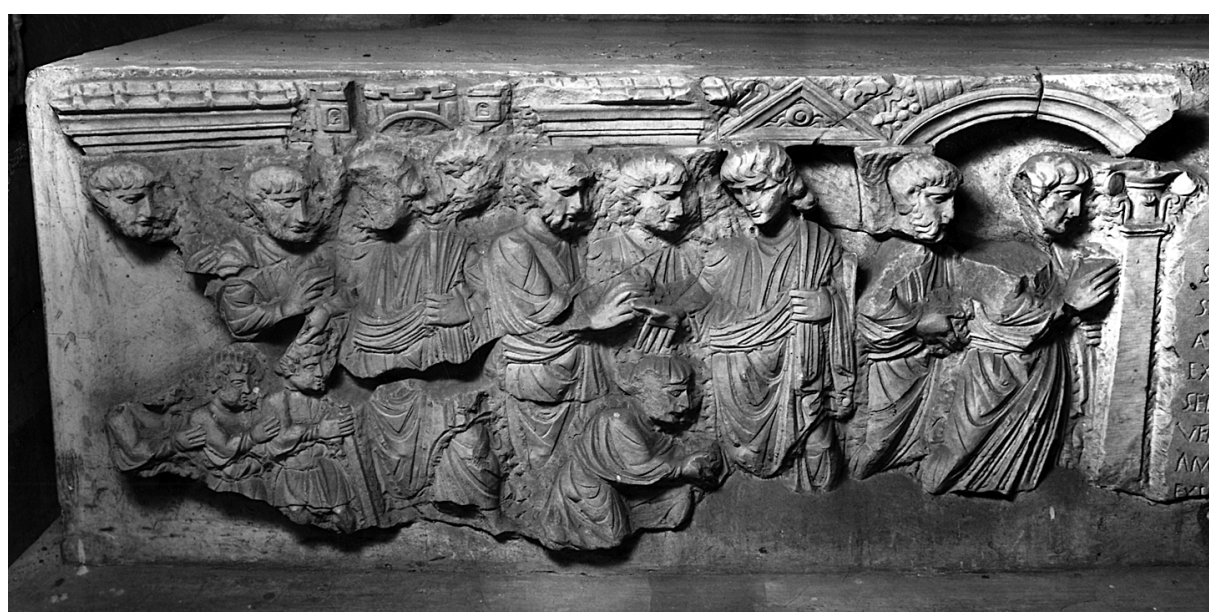

Figure 10.6: The Sarcophagus of Bassa, left front. Photograph: DAIR 1963.1123 (Sansaini).

Christ's victory over death also implies the deceased's journey toward the everlasting reward guaranteed by that Gospel narrative. ${ }^{51}$

It is, then, this particular narrative thrust, with all its promise, that the design of Bassa's sarcophagus seems so artlessly to suspend (Figures 10.1 and 10.6), portraying the healing of the blind men (apparently numbering three not two), the kneeling woman, and even Christ approaching the Bethesda Pool, but replacing the anticipated visual climax with the epitaph's verbal display. ${ }^{52}$ But just how clumsy or cavalier is this monument?

\section{Agency and Identity}

We may never know more about Bassa than her epitaph tells. She died young and lamented, at twenty-two probably not a new bride for Roman girls, pagan and Christian, typically first married in their late teens. ${ }^{53}$ Perhaps the

51 Simon 1938, 208-209 and Nicoletti 1981, 35-40, concerning the narrative thrust of the Bethesda design comparable to that of the Red Sea type.

52 Wilpert 1932, 294: a 'strano combiamento'; Nicoletti 1981, 16: 'L'interruzione ... è senza dubbio estranea allo spirito che informa l'arte cristiana'.

53 Nordberg 1963, 66-68: 'the most usual age at which women in Rome got married was between 15 and 18 years,' though the statistical average of his group (125 women) was 20.4 years of age; Carletti 1977, 39-51: with an average of 20.3 but with half of his examples (90 of 187) falling between 14 and 18 years of age (40-41); Shaw 1987, 30 46: 'late teens' (43). 
complications of childbirth were to blame. ${ }^{54}$ In any case, her age put her in good company: Henric Nordberg's 1963 study of Christian epitaphs yielded an average female life span for the commemorated dead of exactly twenty-two years (22.0). ${ }^{55}$ Bassa also joins the ranks of girls and very young women who disproportionately populate Rome's funerary epigraphy ${ }^{56}-$ an imbalance most likely reflecting the propensity of men to commemorate wives and daughters for the benefit of male public culture. It follows, then, that Gaudentius probably conducted Bassa's last rites, commissioned her monument, and, as the acrostic also suggests (Bassae suae. . . Gaudentius), composed her epitaph. After all, as Éric Rebillard has convincingly argued, the burial and commemoration of Christians was still very much a family affair, immune from the strictures of ecclesiastical control. ${ }^{57}$

But the readers of Bassa's epitaph were also viewers and we should try to put ourselves in the place of those who by intent or coincidence, in the course of funerary rites or annual commemorations and banquets for the dead, may have paused to consider the message(s) of Bassa's memorial. ${ }^{58}$ It is often postulated, as it has been, for example, by Richard Brilliant, Michael Koortbojian, and Jas' Elsner, that the abbreviated scenes on second-century mythological sarcophagi might act as metonymous tableaux, inviting viewers, through analogy and allegory, to identify the deceased with the stories of Meleager or Achilles or Endymion displayed on their coffins. ${ }^{59}$ Fourth-century 'private' art at Rome

54 Carroll 2006, 153-154.

55 Nordberg 1963, 38-40, based on 1254 Christian epitaphs of Roman women (ranging from the third to the sixth century).

56 E.g. Shaw 1987, 34-35; Dresken-Weiland 2004, 149-153, calculating that $32 \%$ of 310 early Christian Roman sarcophagi from the last third of third century to the end of the fourth were utilised for the burial of women as opposed to $30.6 \%$ for men (reversing the trend she observes for earlier pagan sarcophagi).

57 Rebillard 2003, 143-160 and surveyed at Rebillard 2009, 220-230.

58 The viewing context of all such monuments is difficult to establish, a problem compounded in this case by uncertainty on the original location of Bassa's sarcophagus, though placement in a cubiculum, visible to passersby as well as family, may be likely. See, e. g. Fiocchi Nicolai, in Fiocchi Nicolai, Bisconti, and Mazzoleni 2002, 44-46. For more on funerary rites and the regularity of annual commemorative rituals and banquets (refrigeria) in this age see Krautheimer 1960, 31-33; Marinone 2000, 71-80, noting (75) the difficulty of reconstructing these rites in the adverse conditions of the catacombs; Bisconti, Fiocchi Nicolai, et al. 2001, 63-96; and Jensen 2008, 107-143.

59 Brilliant 1984, 124-165, esp. 150 (on the 'metonymous order established by the Roman artists in their creation of a doubly referential system of causality, applicable to the bios of Meleager and to the life of the deceased') and 164 (where artists and patrons collaborate in the construction and reading of a 'metonymous tableau' and linear narrative ceases to govern the composition of the visual program). Koortbojian 1995, 1-22, with emphasis on analogical and symbolic associations between the myths and the life of the deceased; Elsner 1998, 149-54. 
should have been no less susceptible to readings that connected patrons with the narrative and figural imagery they commissioned or deployed. For instance, the interplay of domestic scenes, mythological imagery, and Christian exhortation on the luxurious Casket of Proiecta encouraged viewers not only to reconcile 'complex and even contradictory discourses' but also to imagine and eroticise 'Proiecta's' uxorial life. ${ }^{60}$ Similarly, the juxtaposed Biblical tableaux and conventional (not to say pagan) imagery of the sarcophagus of the noble neophyte Junius Bassus (Figure 11.1) - 'loftier' in death than he had been even as Urban Prefect in 359 - in dialogue with his coffin's Christian epitaph and 'classicising' verse elogium, suggestively linked Bassus both to his aristocratic forebears and to an alternate nobility of witness - especially the Roman Peter and Paul - that included a magisterial Christ figure. ${ }^{61}$ In this regard, his sarcophagus' fecund symbolic and allegorical enticements surely seduced ancient viewers no less successfully than they have modern art historians. ${ }^{62}$

Might, then, some Roman viewers - adept consumers of visual imagery have made more of Bassa's ensemble than a hodge-podge of broken narrative and borrowed verse $?^{63}$ Certainly the patchwork quality of the sarcophagus, with its bricolage quality and Damasan spolia, conforms to an 'aesthetic of appropriation' widely evident in such diverse fourth-century monuments as the Arch of Constantine and the Vergilian cento, wherein Roman eyes, it seems, were readier to recognise thematic unity than the stylistic or generic incongruities that have distracted some modern art historians. ${ }^{64}$ Moreover, the juxtaposition of images and words in Bassa's sarcophagus is surely not as jarring as it first appears. The stranded figure of Christ, who gestures toward, even leans into, the tabula of the epitaph, surely encourages the viewer to understand Bassa's ascension to the 'ethereal home' of the saints as yet another miracle

60 Shelton 1981, with Elsner 1995, 251-258, 266 ('a highly sophisticated parallelism between patron and goddess') and especially Elsner 2003b, 22-36, quote 32. Shelton 1981, 31 considered the casket and the inscription contemporary; as Elsner 2003b, 22 points out, a 'later owner' could have added the inscription.

61 For the similar rhetoric of Constantine's mausoleum/Church of the Holy Apostles see Elsner 2000, 159-162.

62 Malbon 1990, e.g., 134, 152-53, with discussion of earlier studies 22-38; and more recently Elsner 2003a, 82-86 and Suzawa 2008, 99-116. Peter and Paul are prominent in their arrest scenes and in a traditio legis tableau where they flank an enthroned Christ, who also appears in a Jerusalem entry scene and his own arrest scene. For the 'classicising elegiacs' (289) of the elogium see Cameron 2002, 288-292, emending the final distich to '[cedite sublimes] spirantum cedite honores, / [celsius (loftier) est culmen] mors quod huic tribuit'.

63 A good example of interpretive sophistication among 'ordinary' Romans at Clarke 2003, 215-219: 'double entendre' in an Ostian sarcophagus.

64 Clark and Hatch 1981; Elsner 2000, quote 176; McGill 2005, with Kinney 1997, 139 140 , on the challenge presented to modern observers by ancient theomorphic portraits. 
performed by Christ. Wonders once worked - sight restored and health renewed - vouched for by scripture and easily seen as metaphor - thus justify Bassa's assurance to Gaudentius (and others temporarily left behind): from 'death's snares' you, too, will be saved (sospes eris). Perhaps some were even prepared to see Bassa's untimely death glossed metonymically in the trials of those rescued here by Christ's touch and presence, particularly in the image of the kneeling woman (the sole female present in the Bethesda type), to whom Jesus said 'Your faith has healed you (fides tua te salvam fecit)'. ${ }^{65}$ In any case, like them, as her epitaph proclaimed, she 'trusted in God' and followed Christ with a 'pure heart'. ${ }^{66}$ Similarly Christ's restoration of sight to the blind men finds an echo in Bassa's plea that Gaudentius should look up (suspice) to see a scene of salvation and eternal life that was veiled to eyes not touched in some way by Christ's power. Despite the shift in idiom, then - from figural to textual - these and other themes might well seem to link the two halves of Bassa's sarcophagus, making her astral victory but another chapter in the coffin's narrative of spiritual healing and salvation.

Such connections, present on the surface, would not have been hard to imagine. But just as Bassa's epitaph cites a Damasan poem installed elsewhere in the same catacomb - eliding the years that separated Theodosian Rome from the ancient city of the martyrs while also fashioning Bassa as a new kind of witness - might not her sarcophagus also allude to its other intertext? Did some who came upon Bassa's sarcophagus sense the presence of the 'missing' scenes? The healing at Bethesda, the calling of Zacchaeus, and Christ's triumphal procession would then bleed through the words to resituate Bassa's celestial immortality against the background of those long-ago events that had spawned Rome's newest history. To such eyes, Christ of the Bethesdan pool and the palm frond acclamations might have been visible in the epitaph's prominent (and easily recognisable) christo-gram, through which Bassa would live forever (vivens per secula Xpo). ${ }^{67}$ Zacchaeus, told by Luke's Jesus, 'today this house has been saved,' prefigures the salvation of Bassa and her house, swept now into Jesus' universalising proclamation, 'For the Son of Man has come to seek and save what was lost (perierat),' - which also might mean, of course, what has died (pereo). Indeed, the foundations of Bassa's vaunted regna piorum and regia caeli had been set in place by the crucifixion and resurrection that are the narrative

65 Mt 9.21-22: 'Si tetigero tantum vestimentum eius, salva ero.' Et lesus conversus et videns eam dixit: 'Confide, filia; fides tua te salvam fecit.' If not adequate on its own to explain Gaudentius' (or Bassa's) choice of a Bethesda type for his wife's memorial, the presence of the kneeling woman may have cemented its appeal.

66 Compare A8, 'venturumq(ue) deum puro [cum] corde secuta', with Mt 20.34 (on the two blind men at Jericho): 'et confestim viderunt et secuti sunt eum'.

67 Carletti 1998, 53-54 on the high frequency (10\%) of the christo-gram in Roman funerary epigraphy. 
fulfillment of Christ's Jerusalem advent and the implicit dénouement of the Bethesdan imagery.

It would be foolhardy to push such notions too far, to demand a particular set of correlations between the words of Bassa's epitaph and the elements of the Bethesda narrative that her verses have replaced. It may not be irresponsible, however, to think that from this sarcophagus' mix of words, images, and allusions ancient viewers were also tempted to construct meanings that transcended what would have been possible on the basis of the inscribed text or sculpted images alone. Moreover, both the idiosyncrasy of the coffin's design and the bravado of its verse epitaph suggest that Bassa, Gaudentius, and the artisans of some Roman atelier expected viewers to see/read this memorial in some fashion against a background of merit and reward that receded past Rome's martyrial horizons, so recently illuminated by the elogia of Damasus, to the even more distant age of wonders worked by the living Christ on the eve of his own resurrection (and perhaps to the equally ancient astral claims of divinised heroes and emperors).

In other words, Bassa's monument has a no less powerful claim than Proiecta's casket or Junius Bassus's sarcophagus to document a purposeful manipulation of the still fluid signs and symbols that embodied 'religion' in this age. As a less exalted participant in the visual revolution that Jas' Elsner has called the 'deep Christian project of fostering a cohesive sense of identity related to Scripture,' then, Bassa's sarcophagus reflects the efforts of middling Romans to (re-)invent themselves by manipulating a scriptural, poetic, and visual vocabulary that rose to prominence along the cultural front of the postConstantinian decades. ${ }^{68}$ In Bassa's case, episcopally sponsored classicising poetry and art forms made legible through singular and seriatim standardisation were borrowed and bent to the novel expression of personal and social identity. Cumulatively such endeavors might forge the loyalties that allowed Christianity to weather the disputes, schisms, and sectarian violence that often seem to dominate the story of Roma Christiana. Singularly they reveal the array of voices that continually shaped and re-shaped that Christianity.

\section{Bibliography}

Bisconti, F., Fiocchi Nicolai, V. et al. Riti e corredi funerari, in: Christiana loca: Lo spazio cristiano nella Roma del primo millennio 2, edited by L. Pani Ermini (Rome, 2001), 63-96.

Brilliant, R. Mythological Sarcophagi: Proleptic Visions, in: Visual Narratives: Storytelling in Etruscan and Roman Art, by R. Brilliant (Ithaca and London, 1984), $124-165$.

68 Elsner 1995, 247-287, quote 251. 
Cameron, A. The Funeral of Junius Bassus. Zeitschrift für Papyrologie und Epigraphik 139 (2002), 288-292.

Carletti, C. Aspetti biometrici del matrimonio nelle iscrizioni cristiane di Roma. Augustinianum 17 (1977), 39-51.

Carletti, C. 'Un mondo nuovo.' Epigrafia funeraria dei cristiani a Roma in età postcostantiniana. Vetera Christianorum 35 (1998), 39-67.

Carletti, C. Dalla 'pratica aperta' alla 'pratica chiusa': produzione epigrafica a Roma tra V e VIII secolo, in: Roma nell'alto medioevo (Spoleto, 2001), 325-392.

Carroll, M. Spirits of the Dead: Roman Funerary Commemoration in Western Europe (Oxford and New York, 2006).

Clark E. and Hatch, D. The Golden Bough, The Oaken Cross: The Virgilian Cento of Faltonia Betitia Proba (California, 1981).

Clarke, J. R. Art in the Lives of Ordinary Romans: Visual Representation and Non-Elite Viewers in Italy, 100 B.C.-A.D. 315 (Berkeley, Los Angeles, and London, 2003).

Courtney, E. The Fragmentary Latin Poets (Oxford, 1993).

Curran, J. Pagan City and Christian Capital: Rome in the Fourth Century (Oxford, 2000).

Dresken-Weiland, J. Ricerche sui committenti e destinatari dei sarcofagi paleocristiani a Roma, in: F. Bisconti and H. Brandenburg (eds.), Sarcofagi tardoantichi, paleocristiani e altomedievali: Atti della giornata tematica dei Seminari di Archeologia Cristiana (École Française de Rome-8 Maggio 2002) (Vatican City, 2004), 149-153.

Elsner, J. Art and the Roman Viewer: The Transformation of Art from the Pagan World to Christianity (Cambridge, 1995).

Elsner, J. Imperial Rome and Christian Triumph: The Art of the Roman Empire AD 100450 (Oxford and New York, 1998).

Elsner, J. From the Culture of spolia to the Cult of Relics: The Arch of Constantine and the Genesis of Late Antique Forms. Papers of the British School at Rome 68 (2000), $149-184$.

Elsner, J. Inventing Christian Rome: The Role of Early Christian Art, in: Rome the Cosmopolis, edited by C. Edwards and G. Woolf (Cambridge, 2003a), 71-99.

Elsner, J. Visualizing Women in Late Antique Rome: The Projecta Casket, in: Through a Glass Brightly: Studies in Byzantine and Medieval Art and Archaeology Presented to David Buckton, edited by C. Entwistle (Oxford, 2003b), 22-36.

Ferrua, A. Epigrammata Damasiana (Vatican City, 1942).

Ferrua, A. Inscriptiones Christianae Urbis Romae. Vol. 5 (Vatican City, 1971).

Fiocchi Nicolai, V., Bisconti, F. and Mazzoleni, D. The Christian Catacombs of Rome: History, Decoration, Inscriptions (second edition) (Regensburg, 2002).

Fontaine, J. Naissance de la poésie dans l'occident chrétien (Paris, 1981).

Fontaine, J. Damase poète Théodosien: L'imaginaire poétique des epigrammata, in: Saecularia Damasiana: Atti del convegno internazionale per il XVI centenario della morte di papa Damaso I (Vatican City, 1986), 115-145.

Garver, M. Quaelibet Audendi: Fortunatus and the Acrostic. TAPA 123 (1993), 219245.

Gell, A. Art and Agency: An Anthropological Theory (Oxford, 1998).

Gradel, I. Emperor Worship and Roman Religion (Oxford, 2002).

Green, R. P. H. Latin Epics of the New Testament: Juvencus, Sedulius, Arator (Oxford and New York, 2006).

Gurval, R. Caesar's Comet: The Politics and Poetics of an Augustan Myth. Memoirs of the American Academy in Rome 42 (1997), 39-71. 
Jensen, R. M. Dining with the Dead: From the Mensa to the Altar in Christian Late Antiquity, in: Commemorating the Dead: Texts and Artifacts in Context, edited by L. Brink and D. Green (Berlin and New York, 2008), 107-143.

Josi, E. Note sul cimitero di Pretestato III: La sistemazione del materiale epigrafico nel cimitero di Pretestato. Rivista di archeologia cristiana 12 (1935), 7-18.

Kinney, D. Spolia, Damnatio and Renovatio Memoriae. Memoirs of the American Academy in Rome 42 (1997), 117-148.

Knipp, D. 'Christus Medicus' in der frühchristlichen Sarkophagskulptur: Ikonographische Studien der sepulkralkunst des späten vierten Jahrhunderts (Leiden, Boston, and Köln, 1998).

Koch, G. Frühchristliche Sarkophage (Munich, 2000).

Koortbojian, M. Myth, Meaning, and Memory on Roman Sarcophagi (Berkeley, Los Angeles, and London, 1995).

Krautheimer, R. Mensa-Coemeterium-Martyrium. Cahier archéologiques fin de l'antiquité et moyen âge 11 (1960), 15-40.

Lawrence, M. City-Gate Sarcophagi. The Art Bulletin 10 (1927), 1-45.

Lawrence, M. Columnar Sarcophagi in the Latin West: Ateliers, Chronology, Style. The Art Bulletin 14 (1932), 103-185.

Levitan, W. Dancing at the End of the Rope: Optatian Porfyry and the Field of Roman Verse. Transactions of the American Philological Association 115 (1985), 245-269.

MacCormack, S. The Shadows of Poetry: Vergil in the Mind of Augustine (Berkeley, Los Angeles, and London, 1998).

Malbon, E. S. The Iconography of the Sarcophagus of Junius Bassus (Princeton, 1990).

Marinone, M. I riti funerari, in: Christiana loca: Lo spazio cristiano nella Roma del primo millennio 1, edited by L. Pani Ermini (Rome, 2000), 71-80.

Mathews, T. F. The Clash of the Gods: A Reinterpretation of Early Christian Art. Revised and Expanded Edition (Princeton and Oxford, 1999).

Mazzei, B. A proposito del sarcofago di Bethesda delle catacombe di Pretestato, in: F. Bisconti and H. Brandenburg (eds.), Sarcofagi tardoantichi, paleocristiani $e$ altomedievali: Atti della giornata tematica dei Seminari di Archeologia Cristiana (École Française de Rome-8 Maggio 2002) (Vatican City, 2004), 111-130.

McGill, S. Virgil Recomposed: The Mythological and Secular Centos in Antiquity (Oxford and New York, 2005).

Minasi, M. Paralitico, in: Temi di iconografia paleocristiana, edited by F. Bisconti (Vatican City, 2000), 241-243.

Monfrin, F. La guérison du serviteur (Jn 4,43-54): Une nouvelle interprétation des sarcophages de Bethesda. Mélanges de l'École Française de Rome. Antiquité 97 (1985), 979-1020.

Nicoletti, A. I sarcofagi di Bethesda (Milan, 1981).

Noga-Banai, G. Loca Sancta and the Bethesda Sarcophagi, in: Salute e guarigione nella tarda antichità. Atti della giornata tematica dei Seminari di Archeologia Cristiana, edited by H. Brandenburg, S. Heid, and C. Markschies (Vatican City, 2007), $107-$ 123.

Nordberg, H. Biometrical Notes: The Information on Ancient Christian Inscriptions from Rome Concerning the Duration of Life and the Dates of Birth and Death. Acta Instituti Romani Finlandiae 2.2. (Helsinki, 1963).

Pietri, C. and Pietri, L. (eds.). Prosopographie chrétienne du Bas-Empire 2: Prosopographie de l'Italie chrétienne (Rome, 1999-2000).

Ranucci, C. Guarigione del cieco, in: Temi di iconografia paleocristiana, edited by F. Bisconti (Vatican City, 2000), 200. 
Rebillard, É. Religion et sépulture: L'Église, les vivants et les morts dans l'Antiquité tardive (Paris, 2003).

Rebillard, É. The Church, the Living, and the Dead, in: A Companion to Late Antiquity, edited by P. Rousseau (Malden and Oxford, 2009), 220-230.

Rees, R. (ed.). 'Romane memento': Vergil in the Fourth Century (London, 2004).

Rüpke, J. and Glock, A. Fasti Sacerdotum: A Prosopography of Pagan, Jewish, and Christian Religious Officials in the City of Rome, 300 BC to AD 499, translated by D. Richardson (Oxford and New York, 2008).

Sanders, G. Lapides memores. Païens et chrétiens face à la mort: Le témoignage de l'épigraphie funéraire latine, edited by A. Donati, D. Pikhaus, and M. van Uytfanghe (Faenza, 1991).

Scourfield, J. H. D. (ed.). Text and Culture in Late Antiquity: Inheritance, Authority, and Change (Swansea, 2007).

Shelton, K. The Esquiline Treasure (London, 1981).

Simon, M. Sur l'origine des sarcophages chrétiens du type Béthesda. École Française de Rome: Mélanges d'archéologie et d'histoire 55 (1938), 200-223.

Shaw, B. The Age of Roman Girls at Marriage: Some Reconsiderations. Journal of Roman Studies 77 (1987), 30-46.

Sotomayor, M. Sarcofagos romano-cristianos de España: Estudios iconográfico (Granada, 1975).

Spera, L. Praetextati, Coemeterium, in: Lexicon Topographicum Urbis Romae: Suburbium. Vol. 4, edited by A. La Regina (Rome, 2006), 250-261.

Spera, L. Il complesso di Pretestato sulla Via Appia: Storia topografica e monumentale di un insediamento funerario paleocristiano nel suburbio di Roma. Roma Sotterranea Cristiana 12 (Vatican City, 2004).

Suzawa, Y. The Genesis of Early Christian Art: Syncretic Juxtaposition in the Roman World. BAR International Series 1892 (Oxford, 2008).

Tolotti, F. Ricera dei luoghi venerati nella spelunca magna di Pretestato. Rivista di archeologia cristiana 53 (1977), 7-102.

Trout, D. The Verse Epitaph(s) of Petronius Probus: Competitive Commemoration in Late-Fourth-Century Rome. New England Classical Journal 28 (2001), 157-176.

Trout, D. Damasus and the Invention of Early Christian Rome, in: The Cultural Turn in Late Ancient Studies: Gender, Asceticism, and Historiography, edited by D. B. Martin and P. Cox Miller (Durham, 2005), 298-315.

Warwick, H. H. A Vergil Concordance (Minneapolis, 1975).

Wilpert, J. I sarcofagi cristiani antichi Vol. 2 (Vatican City, 1932). 